\title{
Therapeutic Role of Leaf Pulp of Carpobrotus edulis on Chromium VI Induced Toxicity in Wistar Rats
}

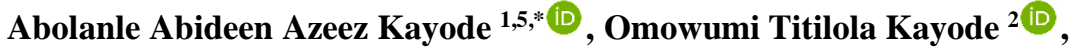 \\ Anthony Ikponwmosa Obaseki ${ }^{3}$ (D), Great Oluwamayokun Alabi ${ }^{4}$ (D), Buyiswa Hlangothi ${ }^{5}$ (D), \\ Sunday Adeniyi Ogunlaja 5 (D)
}

1 Phytomedicine Research, Drug Discovery \& Development Laboratory, Department of Biochemistry, School of Basic Medical Sciences, Babcock University, Ilishan-Remo, Ogun State, Nigeria; kayodeab@babcock.edu.ng (A.A.A.K.);

2 Biochemistry Unit, Department of Biological Sciences, Mountain Top University, Ogun State, Nigeria; wumikayot@gmail.com (O.T.K.);

3 Department of Chemistry \& Biochemistry, Miami University, Oxford, OH 45056, USA; obasekia@ miamioh.edu (A.I.O.);

4 Department of Physiology, School of Basic Medical Sciences, Babcock University, Ilishan-Remo, Ogun State, Nigeria; alabig@babcock.edu.ng (G.O.A.);

5 Department of Chemistry, Nelson Mandela University, Port Elizabeth, South Africa; buyiswa.hlangothi@mandela.ac.za (B.H.), adeniyi.ogunlaja@mandela.ac.za (S.A.O.);

* Correspondence: kayodeab@babcock.edu.ng (A.A.A.K.); bolakayot@gmail.com (A.A.A.K.);

Scopus Author ID 35224908600

Received: 26.03.2021; Revised: 25.06.2021; Accepted: 30.06.2021; Published: 12.09.2021

Abstract: The leaf pulp of Carpobrotus edulis has antibacterial, antifungal, and tissue regeneration abilities. Chromium is a ubiquitous contaminant that has raised a major concern due to its level of toxicity. This study investigated the therapeutic role of leaf pulp of Carpobrotus edulis on chromium VI-induced toxicity in male Wistar rats. Thirty rats were divided into five groups of six rats, each comprising group 1 (control group), given $0.5 \mathrm{~mL}$ of de-ionized water. Group 2 was pre-treated with $0.5 \mathrm{~mL}$ of the leaf pulp for seven consecutive days, and afterward, $5 \mathrm{mg} / \mathrm{kg}$ potassium dichromate $\left(\mathrm{K}_{2} \mathrm{Cr}_{2} \mathrm{O}_{7}\right)$ was administered for another seven days. Group 3 was given $5 \mathrm{mg} / \mathrm{kg} \mathrm{K}_{2} \mathrm{Cr}_{2} \mathrm{O}_{7}$ for seven days and $0.5 \mathrm{~mL}$ of the leaf pulp after that. Group 4 was given only $5 \mathrm{mg} / \mathrm{kg} \mathrm{K}_{2} \mathrm{Cr}_{2} \mathrm{O}_{7}$ for 7 days, and group 5 was treated with $0.5 \mathrm{~mL}$ of the plant leaf pulp for 14 days. The rats were sacrificed under mild diethyl ether anesthesia twenty-four hours after the last treatment. The blood, liver, and kidney were collected and used for hematological, biochemical, and morphological analyses. Significant increases $(\mathrm{p}<0.05)$ were observed in WBC, NEUT, and MON while significant decreases were observed in RBC, $\mathrm{PCV}$, and hemoglobin in group 4 compared to the control. In the pre-treated (group 2) and the therapeutic (group 3) groups administered leaf pulp of Carpobrotus edulis, the hematological parameters were increased compared to the control. The levels of MDA, SOD, GST, and catalase in the liver and kidney were significantly $(\mathrm{p}<0.05)$ depleted in group 4 when compared to control, whereas these parameters were significantly $(\mathrm{p}<0.05)$ elevated in the group treated with the leaf pulp only. The levels of AST, ALT, and ALP showed a significant $(\mathrm{p}<0.05)$ decrease in group 4 when compared to the control; however, no significant $(\mathrm{p}<0.05)$ change was observed in all the other groups. There was a significant increase $(\mathrm{p}<0.05)$ in the urea level in group 4 , while creatinine level showed no significant change. Other biochemical parameters such as LDL, TRIG, Total and direct bilirubin showed no significant change in group 4 compared to the control.

Similarly, there was no significant change in the electrolyte parameters. There was a significant decrease in HDL and CHOL levels in group 2 when compared to the control. Summarily, the leaf pulp of $C$. edulis appears to reverse the toxicity caused by chromium VI probably through its antioxidative effects and its ameliorative effect on the liver and kidney functions. This may partly justify the folkloric use of the leaf juice of the plant. 
Keywords: Carpobrotus edulis; Chromium VI; leaf pulp; toxicity; antioxidants; organ damage.

(c) 2021 by the authors. This article is an open-access article distributed under the terms and conditions of the Creative Commons Attribution (CC BY) license (https://creativecommons.org/licenses/by/4.0/).

\section{Introduction}

Carpobrotus edulis ( $C$. edulis) doubles as a medicinal and edible succulent plant belonging to the family Aizoaceae, which is considered South Africa's most diverse and abundant plant family the least studied for medicinal properties. It is also known as the 'sour fig plant' or 'highway ice plant'. C. edulis is common in the Eastern and Western Cape regions of South Africa and is also found along with other coastal areas of Africa and other continents [1].

Researches have shown that the leaf pulp of $C$. edulis is used to treat oral and gastrointestinal infections, inflammation, and diabetes [2-4]. Phytochemicals such as phenols, saponins, flavonoids flavonols, alkaloids, and tannins are reportedly present in C. edulis [5]. These phytochemicals are responsible for the neuroprotective, antioxidant, antifungal, antidiabetic, antibacterial, antiviral, cardioprotective, anti-inflammatory, and anticancer properties observed in this plant, making it a potential medicinal plant for drug development [1]. According to a study by Rocha et al., 2016, C. edulis was proven to be nutritionally suitable for human consumption [6].

Chromium $(\mathrm{Cr})$ is one of the main industrial wastes which causes health problems both in animals and humans, with $\mathrm{Cr}$ (III) and $\mathrm{Cr}$ (VI) being the most common and prevalent of the oxidation states of chromium [7]. Chromium can be absorbed into the human body through the mouth, skin, or inhalation. Cr (VI) is more toxic and easily absorbed than chromium (III), especially when administered orally by entering the cell by facilitated diffusion [8]. Studies have shown that industrial workers exposed to $\mathrm{Cr}$ (VI) through inhalation have a high occurrence of lung cancer [9]. The kidneys, liver, bone, and spleen of humans have the highest concentration of chromium. Oral exposure to $\mathrm{Cr}$ (VI) in drinking water has been discovered to be carcinogenic after ingestion [9]. For humans not exposed to industrial wastes, the major possible sources of oral exposure to $\mathrm{Cr}$ (VI) are food and drinking water, with the greatest amount being found in vegetables, fruits, meat, and fish. Exposure to $\mathrm{Cr}$ (VI) leads to cellular toxicity, chromosomal and DNA damage by activating oxidative stress pathways [7]. The major targets of $\mathrm{Cr}$ (VI) in the human body are the liver, kidneys, immune, hematological and gastrointestinal systems [8].

Carpobrotus edulis has been reported to have antioxidant and anticarcinogenic properties; evidence regarding the relationship between $C$. edulis and toxicity of chromium VI is unknown, and information on the effect of leave pulp of the medicinal plant on chromium VI induced toxicity on organs such as liver and kidney is also unknown. Therefore, this study investigates the therapeutic role of leaf pulp of Carpobrotus edulis on chromium VI-induced toxicity in Wistar rats.

\section{Materials and Methods}

\subsection{Plant material and extraction of the leaf pulp.}

The fresh leaves of C. edulis were collected in March 2018 within the premises of the South Campus, Nelson Mandela University of Port Elizabeth, South Africa, and were identified 
by the curator of the Botanical garden of the same University. The leaves were placed in a juice extractor, and the juice extracted. The process was repeated to get the desired quantity needed.

\subsection{Animal treatment.}

Thirty Adult male Wister rats weighing $170 \mathrm{~g}$ were obtained from Animal House of the Department of Physiology, University of Ibadan. They were housed and divided into groups:

Group 1 was administered $0.5 \mathrm{~mL}$ of distilled water.

Group 2 received $0.5 \mathrm{~mL}$ of leaf pulp followed by $5 \mathrm{mg} / \mathrm{kg}$ potassium dichromate $\left(\mathrm{K}_{2} \mathrm{Cr}_{2} \mathrm{O}_{7}\right)$, Group 3 was administered $5 \mathrm{mg} / \mathrm{kg} \mathrm{K} \mathrm{K}_{2} \mathrm{Cr}_{2} \mathrm{O}_{7}$ followed by $0.5 \mathrm{~mL}$ of the leaf pulp.

Group 4 received $5 \mathrm{mg} / \mathrm{kg} \mathrm{K}_{2} \mathrm{Cr}_{2} \mathrm{O}_{7}$ only

Group 5 received $0.5 \mathrm{~mL}$ of the plant juice only.

Twenty-four hours after the last treatment, the rats were sacrificed and the organs harvested for analysis.

\subsection{Measurement of biochemical parameters.}

Randox diagnostics kits were used for the Aspartate Aminotransferase (AST), Alanine Aminotransferase (ALT), and Alkaline Phosphate (ALP) assays following the principles described by Reitman and Frankle [10]. HDL - and LDL - cholesterol were determined according to the principle described by Trinder [11]. Triglycerides were determined following the CHOD - PAP enzymatic colorimetric method of Trinder [12]. The method of Veniamin and Vakirtzi-Lemonias [13] was used to determine urea concentration in plasma. MDA was carried out according to the method of Varshey and Kale [14]. Glutathione -s- transferase was carried out using the methods of Habig et al., [15]. Superoxide dismutase was determined according to the method of Misra and Fridovich [16]. Catalase activity was done using the method of Sinha et al. [17]. Other tests carried out include electrolyte, total and direct bilirubin. Statistical analysis was done using one-way ANOVA.

\section{Results and Discussion}

Table 1 shows a significant $(\mathrm{p}<0.05)$ increase in the level of white blood cells in the group administered $5 \mathrm{mg} / \mathrm{kg}$ body weight of $\mathrm{K}_{2} \mathrm{Cr}_{2} \mathrm{O}_{7}(\mathrm{Cr}$ (VI)) only (Group 4) when compared to the control, while there was no significant $(\mathrm{p}<0.05)$ change in the other treatment groups. However, there was a significant $(\mathrm{p}<0.05)$ decrease in red blood cell count in the group administered $5 \mathrm{mg} / \mathrm{kg}$ body weight of $\mathrm{Cr}$ (VI) only (Group 4) when compared to the control and other groups. Similarly, there was a significant decrease in PCV with animals treated with $5 \mathrm{mg} / \mathrm{kg}$ body weight of $\mathrm{Cr}$ (VI) only compared to the control. In addition, the group pre-treated with $0.5 \mathrm{~mL} \mathrm{C}$. edulis and $5 \mathrm{mg} / \mathrm{kg}$ body weight of Cr (VI) (Group 2) showed no significant change in the hemoglobin concentration when compared to other groups except for the group treated with $5 \mathrm{mg} / \mathrm{kg}$ body weight of $\mathrm{Cr}$ (VI) only (Group 4) which showed a significant decrease.

The platelets count in the group treated with $0.5 \mathrm{~mL} \mathrm{C.} \mathrm{edulis} \mathrm{only} \mathrm{(Group} \mathrm{5)} \mathrm{showed}$ a significant $(\mathrm{p}<0.05)$ increase as compared to control and other groups. Blood lymphocytes in groups treated with $5 \mathrm{mg} / \mathrm{kg}$ body weight of $\mathrm{Cr}$ (VI) only (Group 4) showed a significant $(\mathrm{p}<0.05)$ increase as compared with control and other groups, which showed no significant change. Animals treated with $5 \mathrm{mg} / \mathrm{kg}$ body weight of Cr (VI) only (Group 4) showed significant change in monocyte compared with the control and other groups except group 2. 
Animals treated with $5 \mathrm{mg} / \mathrm{kg}$ body weight of Cr (VI) only (Group 4) showed a significant increase in neutrophils when compared to the control and other groups except (Group 3), which showed no significant change.

Table 1. Concentrations of Heamatological Parameters in the treated rats after 14 days.

\begin{tabular}{l|l|l|l|l|l}
$\begin{array}{l}\text { Haematological } \\
\text { Parameters }\end{array}$ & $\begin{array}{l}\text { Group } \\
\text { (Control) }\end{array}$ & Group 2 & Group 3 & Group 4 & Group 5 \\
\hline WBC $\left(x 10^{\wedge 2} / \mathrm{ul}\right)$ & $58.50 \pm 6.56^{\mathrm{b}}$ & $51.50 \pm 6.03^{\mathrm{ab}}$ & $36.66 \pm 7.06^{\mathrm{a}}$ & $108.33 \pm 8.64^{\mathrm{c}}$ & $39 \pm 4.47^{\mathrm{ab}}$ \\
\hline RBC $\left(\mathrm{x} 10^{\wedge 3} / \mathrm{ul}\right)$ & $4.49 \pm 0.44^{\mathrm{b}}$ & $4.36 \pm 0.50^{\mathrm{b}}$ & $4.36 \pm 0.20^{\mathrm{b}}$ & $2.27 \pm 0.31^{\mathrm{a}}$ & $4.04 \pm 0.15^{\mathrm{b}}$ \\
\hline PCV $\%)$ & $35.72 \pm 4.77^{\mathrm{b}}$ & $34.70 \pm 1.01^{\mathrm{b}}$ & $31.33 \pm 1.35^{\mathrm{ab}}$ & $22.73 \pm 1.34^{\mathrm{a}}$ & $37.85 \pm 5.14^{\mathrm{b}}$ \\
\hline HGB $(\mathrm{g} / \mathrm{dl})$ & $11.70 \pm 1.74^{\mathrm{b}}$ & $10.55 \pm 0.425^{\mathrm{b}}$ & $9.67 \pm 0.89^{\mathrm{ab}}$ & $7.2 \pm 54^{\mathrm{a}}$ & $11.58 . \pm 1.10^{\mathrm{b}}$ \\
\hline PLAT $\left(\mathrm{x} 10^{\wedge 3} / \mathrm{ul}\right)$ & $308 \pm 23.64^{\mathrm{a}}$ & $190 \pm 7.52^{\mathrm{a}}$ & $282.33 \pm 49.54^{\mathrm{a}}$ & $203.33 \pm 43.55^{\mathrm{a}}$ & $483.33 \pm 87.00^{\mathrm{b}}$ \\
\hline LYMPH $(\%)$ & $51.50 \pm 0.62^{\mathrm{b}}$ & $41.33 \pm 1.74^{\mathrm{a}}$ & $44.50 \pm 4.48^{\mathrm{ab}}$ & $64.50 \pm 3.35^{\mathrm{c}}$ & $45.67 \pm 3.11^{\mathrm{ab}}$ \\
\hline MON $(\%)$ & $1.67 \pm 0.21^{\mathrm{a}}$ & $4.00 \pm 1.10^{\mathrm{c}}$ & $2.00 \pm 0.37^{\mathrm{a}}$ & $4.67 \pm 0.56^{\mathrm{c}}$ & $2.00 \pm 00^{\mathrm{a}}$ \\
\hline EOS $(\%)$ & $1.50 \pm 0.34^{\mathrm{a}}$ & $2.67 \pm 0.21^{\mathrm{c}}$ & $0.83 \pm 0.17^{\mathrm{a}}$ & $2.50 \pm 0.22^{\mathrm{b}}$ & $1.50 \pm 0.22^{\mathrm{a}}$ \\
\hline NEUT $(\%)$ & $36.67 \pm 1.33^{\mathrm{a}}$ & $48.67 \pm 2.49^{\mathrm{bc}}$ & $43.17 \pm 1.42^{\mathrm{ab}}$ & $52.50 \pm 1.93^{\mathrm{c}}$ & $42.67 \pm 4.42^{\mathrm{ab}}$ \\
\hline MCV $(\mathrm{Fl})$ & $78.67 \pm 4.96^{\mathrm{a}}$ & $78.30 \pm 2.42^{\mathrm{a}}$ & $79.88 \pm 5.80^{\mathrm{a}}$ & $67.38 \pm 4.34^{\mathrm{a}}$ & $70.43 \pm 3.21^{\mathrm{a}}$ \\
\hline MCH $(\mathrm{pg})$ & $25.45 \pm 1.97^{\mathrm{b}}$ & $20.22 \pm 1.46^{\mathrm{a}}$ & $25.17 \pm 0.86^{\mathrm{b}}$ & $17.50 \pm 0.50^{\mathrm{a}}$ & $25.25 \pm 2.37^{\mathrm{b}}$
\end{tabular}

(Each value represents the mean \pm SEM).

$\mathrm{a}, \mathrm{b}, \mathrm{c}=$ values within a row not sharing a common superscript letter were significantly different, $\mathrm{p}<0.05$.

There was no significant change in MCV levels in all the groups. A significant decrease was observed in $\mathrm{MCH}$ levels with animals treated with $5 \mathrm{mg} / \mathrm{kg}$ body weight of $\mathrm{Cr}$ (VI) only (Group 4) except group 3, which showed no significant ( $<<0.05)$ change. The group treated with $5 \mathrm{mg} / \mathrm{kg}$ body weight of $\mathrm{Cr}$ (VI) only (Group 4) showed a significant decrease in the MCHC levels when compared with the control

Table 2 shows the results obtained for the antioxidant property of the leaf pulp of Carpobrotus edulis against chromium VI-induced toxicity. A significant decrease $(\mathrm{p}<0.05)$ in liver GST in animals treated with $5 \mathrm{mg} / \mathrm{kg}$ body weight of Cr (VI) only (Group 4) was observed when compared to the control and the other groups. Similarly, the kidney GST showed a significant decrease in the animals treated with $5 \mathrm{mg} / \mathrm{kg}$ body weight of $\mathrm{Cr}$ (VI)

(Group 4) compared to the control with the highest increase in the group treated with $0.5 \mathrm{~mL}$ C. edulis (Group 5). There was a significant decrease $(\mathrm{p}<0.05)$ in liver SOD in the groups treated with $5 \mathrm{mg} / \mathrm{kg}$ body weight of $\mathrm{Cr}$ (VI) only (Group 4) when compared to the control and group 5. Similarly, the kidney SOD in animals treated with $5 \mathrm{mg} / \mathrm{kg}$ body weight of Cr (VI) only (Group 4) showed a significant decrease compared to the control and the other groups. There was no significant change in the liver Catalase in all the groups except for group 4. The kidney catalase in the group treated with $5 \mathrm{mg} / \mathrm{kg}$ body weight of $\mathrm{Cr}$ (VI) only (Group 4) gave a significant decrease compared to the control and the other groups except for group 2 , which showed no significant change.

Liver MDA levels gave a significant $(\mathrm{p}<0.05)$ increase in the group treated with 5 $\mathrm{mg} / \mathrm{kg}$ body weight of Cr (VI) only (Group 4) when compared to the control and the other groups with kidney MDA showing the similar result. From Table 3, 4, and 5 it was observed that there was a significant $(\mathrm{p}<0.05)$ increase in the urea concentrations in the groups treated with $5 \mathrm{mg} / \mathrm{kg}$ body weight of $\mathrm{Cr}$ (VI) only (Group 4) when compared to the control and the other groups, except group 2 which showed no significant difference. There was no significant change in creatinine levels in all the groups except groups 2 and 5. There was a significant ( $p$ $<0.05)$ decrease in AST, ALP, and ALT levels in the group treated with $5 \mathrm{mg} / \mathrm{kg}$ body weight of $\mathrm{Cr}$ (VI) only (Group 4) when compared to the control. There was a significant decrease in HDL levels in the group treated with $0.5 \mathrm{~mL} \mathrm{C}$. edulis and $5 \mathrm{mg} / \mathrm{kg}$ body weight of $\mathrm{Cr}$ (VI) (Group 2) compared to the control and the other groups. There was no significant difference in 
LDL levels in all the groups. Cholesterol levels decreased significantly in the group treated with $0.5 \mathrm{~mL} \mathrm{C}$. edulis and $5 \mathrm{mg} / \mathrm{kg}$ body weight of Cr (VI) (Group 2) compared to the control and the other groups. In addition, there was no significant change in triglycerides in all the groups. Group 4 exhibited no significant change in total bilirubin compared to the control and the other groups but significantly increased $(\mathrm{p}<0.05)$ in direct bilirubin. There was a significant increase in total protein in group 5 (treated with $0.5 \mathrm{~mL} \mathrm{C.} \mathrm{edulis)} \mathrm{compared} \mathrm{to} \mathrm{the} \mathrm{control} \mathrm{and}$ other groups.

Table 2. Concentrations of antioxidant parameters in the treated rat after 14 days.

\begin{tabular}{|c|c|c|c|c|c|}
\hline Antioxidant parameters & Control & Group2 & Group 3 & Group 4 & Group 5 \\
\hline L.GST $(\mu \mathrm{mol} / \mathrm{ml})$ & $128.99 \pm 9.4^{\mathrm{c}}$ & $99.00 \pm 7.71^{\mathrm{b}}$ & $107.54 \pm 7.18^{\mathrm{bc}}$ & $64.80 \pm 7.74^{\mathrm{a}}$ & $123.84 \pm 4.72^{\mathrm{c}}$ \\
\hline L.SOD $(\mu \mathrm{mol} / \mathrm{ml} / \mathrm{min})$ & $144.24 \pm 1.83^{b}$ & $135.72 \pm 0.89^{\mathrm{a}}$ & $133.58 \pm 5.48^{\mathrm{a}}$ & $131.44 \pm 0.05^{\mathrm{a}}$ & $146.34 \pm 0.43^{b}$ \\
\hline L.CAT $(\mu \mathrm{mol} / \mathrm{ml} / \mathrm{min})$ & $652.72 \pm 7.52^{\mathrm{b}}$ & $651.96 \pm 4.73^{\mathrm{b}}$ & $668.47 \pm 3.41^{b}$ & $608 \pm 19.16^{\mathrm{a}}$ & $644.60 \pm 7.54^{b}$ \\
\hline L.MDA $(\mu \mathrm{mol} / \mathrm{ml})$ & $9.73 \pm 0.97^{\mathrm{a}}$ & $34.96 \pm 1.85^{\mathrm{b}}$ & $17.07 \pm 1.12^{\mathrm{b}}$ & $46.79 \pm 2.19^{\mathrm{d}}$ & $8.86 \pm 0.24^{\mathrm{a}}$ \\
\hline K.GST $(\mu \mathrm{mol} / \mathrm{ml})$ & $83.84 \pm 4.07^{\mathrm{b}}$ & $82.24 \pm 3.20^{\mathrm{b}}$ & $81.36 \pm 3.27^{\mathrm{b}}$ & $64.60 \pm 5.98^{\mathrm{a}}$ & $109.19 \pm 2.60^{\mathrm{c}}$ \\
\hline K.SOD $(\mu \mathrm{mol} / \mathrm{ml} / \mathrm{min})$ & $112.55 \pm 0.89^{\mathrm{c}}$ & $105.14 \pm 1.19^{\mathrm{b}}$ & $107.25 \pm 0.65^{\mathrm{b}}$ & $96.56 \pm 1.02^{\mathrm{a}}$ & $114.80 \pm 1.00^{\mathrm{c}}$ \\
\hline K.CAT $(\mu \mathrm{mol} / \mathrm{ml} / \mathrm{min})$ & $656.05 \pm 15.5^{\mathrm{bc}}$ & $627.31 \pm 13.00^{\mathrm{ab}}$ & $652.10 \pm 6.62^{\mathrm{bc}}$ & $619.54 \pm 15.50^{\mathrm{a}}$ & $660.37 \pm 5.20^{\mathrm{c}}$ \\
\hline K.MDA $(\mu \mathrm{mol} / \mathrm{ml})$ & $13.56 \pm 0.81^{\mathrm{a}}$ & $25.97 \pm 0.46^{\mathrm{b}}$ & $26.45 \pm 3.67^{b}$ & $41.86 \pm 3.97^{\mathrm{c}}$ & $11.40 \pm 0.65^{\mathrm{a}}$ \\
\hline
\end{tabular}

(Each value represents the mean \pm SEM).

$\mathrm{abc}=$ values within a row not sharing a common superscript letter were significantly different, $\mathrm{p}<0.05$.

Table 3. Concentrations of some biochemical parameters in the treated groups after 14 days.

\begin{tabular}{l|l|l|l|l|l} 
Parameters & Control & Group 2 & Group 3 & Group 4 & Group 5 \\
\hline ALP(UI/L) & $113.50 \pm 16.28^{\mathrm{b}}$ & $93.00 \pm 17.23^{\mathrm{ab}}$ & $98.67 \pm 22.82^{\mathrm{ab}}$ & $63.33 \pm 6.14^{\mathrm{a}}$ & $86.50 \pm 3.44^{\mathrm{ab}}$ \\
\hline AST(UI/L) & $133.83 \pm 30.97^{\mathrm{b}}$ & $48.50 \pm 7.46^{\mathrm{a}}$ & $79.67 \pm 4.18^{\mathrm{a}}$ & $44.17 \pm 5.54^{\mathrm{a}}$ & $61.33 \pm 9.68^{\mathrm{a}}$ \\
\hline ALT(UI/L) & $69.33 \pm 5.70^{\mathrm{b}}$ & $59.17 \pm 6.69^{\mathrm{ab}}$ & $60.83 \pm 5.61^{\mathrm{ab}}$ & $50.67 \pm 3.60^{\mathrm{a}}$ & $62.00 \pm 4.77^{\mathrm{ab}}$ \\
\hline HDL(UI/L) & $72.65 \pm 9.01^{\mathrm{b}}$ & $44.95 \pm 7.70^{\mathrm{a}}$ & $65.76 \pm 4.82^{\mathrm{b}}$ & $67.31 \pm 3.01^{\mathrm{b}}$ & $69.13 \pm 2.93^{\mathrm{b}}$ \\
\hline LDL(UI/L) & $17.14 \pm 2.41^{\mathrm{a}}$ & $23.91 \pm 2.67^{\mathrm{a}}$ & $18.66 \pm 2.34^{\mathrm{a}}$ & $25.83 \pm 4.42^{\mathrm{a}}$ & $18.68 \pm 1.65^{\mathrm{a}}$ \\
\hline Cholesterol(mg/L) & $115.83 \pm 6.50^{\mathrm{b}}$ & $89.17 \pm 11.02^{\mathrm{a}}$ & $115.67 \pm 2.82^{\mathrm{b}}$ & $111.33 \pm 4.81^{\mathrm{b}}$ & $115.17 \pm 4.53^{\mathrm{b}}$ \\
\hline Triglyceride(mg/L) & $22.49 \pm 3.42^{\mathrm{a}}$ & $20.68 \pm 2.81^{\mathrm{a}}$ & $21.68 \pm 2.17^{\mathrm{a}}$ & $18.62 \pm 2.60^{\mathrm{a}}$ & $22.08 \pm 2.35^{\mathrm{a}}$ \\
\hline Total Bilirubin (g/L) & $5.26 \pm 0.59^{\mathrm{a}}$ & $7.52 \pm 0.68^{\mathrm{c}}$ & $4.18 \pm 0.40^{\mathrm{a}}$ & $5.95 \pm 1.11^{\mathrm{abc}}$ & $6.52 \pm 0.54^{\mathrm{bc}}$ \\
\hline Direct Bilirubin $(\mathrm{g} / \mathrm{L})$ & $0.70 \pm 0.68^{\mathrm{a}}$ & $1.02 \pm 0.09^{\mathrm{b}}$ & $0.600 \pm 0.063^{\mathrm{a}}$ & $0.95 \pm 0.67^{\mathrm{b}}$ & $0.83 \pm 0.08^{\mathrm{ab}}$ \\
\hline Total Protein $(\mathrm{g} / \mathrm{L})$ & $3.08 \pm 0.38^{\mathrm{a}}$ & $3.00 \pm 0.41^{\mathrm{a}}$ & $3.60 \pm 0.14^{\mathrm{ab}}$ & $2.32 \pm 0.32^{\mathrm{a}}$ & $4.68 \pm 0.81^{\mathrm{b}}$
\end{tabular}

(Each value represents the mean \pm SEM)

$\mathrm{abc}=$ values within a row not sharing a common superscript letter were significantly different, $\mathrm{p}<0.05$.

Table 4. Concentrations of electrolytes in the treated rats after 14 days.

\begin{tabular}{l|l|l|l|l|l} 
Parameters & Control & Group 2 & Group 3 & Group 4 & Group 5 \\
\hline $\mathrm{Na}^{+}$ & $110.83 \pm 1.68^{\mathrm{a}}$ & $145.50 \pm 20.74^{\mathrm{a}}$ & $144.67 \pm 22.00^{\mathrm{a}}$ & $146.00 \pm 21.54^{\mathrm{a}}$ & $111.50 \pm 1.93^{\mathrm{a}}$ \\
\hline $\mathrm{K}^{+}$ & $3.56 \pm 0.42^{\mathrm{a}}$ & $8.52 \pm 2.15^{\mathrm{a}}$ & $8.53 \pm 2.19^{\mathrm{a}}$ & $6.77 \pm 2.13^{\mathrm{a}}$ & $3.25 \pm 0.08^{\mathrm{a}}$ \\
\hline $\mathrm{Ca}$ & $10.36 \pm 0.11^{\mathrm{a}}$ & $14.02 \pm 2.24^{\mathrm{a}}$ & $14.18 \pm 2.28^{\mathrm{a}}$ & $14.04 \pm 2.33^{\mathrm{a}}$ & $10.42 \pm 0.167^{\mathrm{a}}$ \\
\hline $\mathrm{Cl}$ & $103.67 \pm 10.18^{\mathrm{a}}$ & $109.33 \pm 4.00^{\mathrm{a}}$ & $111.00 \pm 18.18^{\mathrm{a}}$ & $117.67 \pm 13.04^{\mathrm{a}}$ & $102.00 \pm 6.27^{\mathrm{a}}$
\end{tabular}

(Each value represents the mean \pm SEM)

$a b c=$ values within a row not sharing a common superscript letter were significantly different, $\mathrm{p}<0.05$.

Table 5. Concentrations of renal parameters in the treated groups after 14 days.

\begin{tabular}{l|l|l|l|l|l} 
Parameters & Control & Group 2 & Group 3 & Group 4 & Group 5 \\
\hline Urea $(\mathrm{mg} / \mathrm{L})$ & $21.60 \pm 1.46^{\mathrm{a}}$ & $44.17 \pm 7.53^{\mathrm{ab}}$ & $26.41 \pm 2.55^{\mathrm{a}}$ & $54.17 \pm 14.07^{\mathrm{b}}$ & $26.67 \pm 2.04^{\mathrm{a}}$ \\
\hline Creatinine $(\mathrm{g} / \mathrm{L})$ & $0.87 \pm 0.44^{\mathrm{a}}$ & $1.10 \pm 0.34^{\mathrm{b}}$ & $0.31 \pm 0.07^{\mathrm{ab}}$ & $0.46 \pm 0.08^{\mathrm{ab}}$ & $0.19 \pm 0.05^{\mathrm{a}}$
\end{tabular}

(Each value represents the mean \pm SEM)

$\mathrm{abc}=$ values within a row not sharing a common superscript letter were significantly different, $\mathrm{p}<0.05$.

Chromium (VI) which is utilized in metal, leather, textile, pharmaceutical, and paint industries, is also found in food and water. It has also been discovered to cause toxic effects in humans $[18,19]$. Therefore, the use of Carpobrotus edulis brings a novel option in chromium therapy. In this context, the present study investigated the protective and therapeutic role of leaf pulp of $C$. edulis on toxicity induced by chromium VI in adult male Wistar rats. The results showed that oral administration of potassium dichromate caused a significant decrease in 
hematological indices such as $\mathrm{Hb}, \mathrm{PCV}, \mathrm{RBC}, \mathrm{MCH}$, and $\mathrm{MCHC}$, and this is similar to the findings by Abedi et al., 2013 [20] (common carp (Cyprinus Carpio), Kim \& Kang, 2016 [21] (Juvenile rockfish) and Saha et al., 2017 [22] (rats) where a decrease in the RBC count, hematocrit and hemoglobin levels were also reported. The drop in these hematological indices in chromate-treated rats showed that $\mathrm{Cr}$ (VI) induces anemia which could be caused by the reactive species of chromate. Microcytic and hypochromic anemia has been shown to be linked with a reduced level of $\mathrm{MCH}$ and $\mathrm{MCHC}$, which was the case in chromium administration.

The reduced hemoglobin level could also result from the inhibition in the production of hemoglobin due to decreasing glycine and succinyl pools [22]. The decline in hemoglobin level could be linked to a change in the structure of heme, thereby causing a disturbance in the production of hemoglobin. Inhibiting the enzyme activity in hemoglobin production may also be the reason for the decline in hemoglobin level in this study [23]. Kumar and Banerjee, 2016 reported that heavy metals directly affect the hematopoietic stem cells in the spleen and kidney with unusual membrane permeability, thereby leading to anemia by reducing the oxygen supply as a result of decreased red blood cell concentration and hemoglobin level [24]. The administration of leaf pulp of C. edulis caused a significant increase in the levels of $\mathrm{Hb}, \mathrm{PCV}$, $\mathrm{RBC}, \mathrm{MCH}$, and MCHC, suggesting that the plant could protect against the adverse effect of chromate. Furthermore, administration of chromium VI exhibited a significant increase in white blood cell count in this study, portraying a stimulation of the defense mechanism, and this was also observed in a study of some experimental animals by Zhumabaeva et al. (2014) where they developed leucocytosis after the $30^{\text {th }}$ day of treatment with $\mathrm{Cr}$ (VI) with high production of immature white blood cells. In another study by Lebedev et al. (2018), a moderate increase in white blood cell count was observed [25, 26]. Contrarily, Saha et al., 2017 recorded a decrease in the white blood cell count, resulting from damage to the hematopoietic stem cells caused by chromium induction. Blood lymphocytes in groups treated with $5 \mathrm{mg} / \mathrm{kg}$ body weight of $\mathrm{Cr}(\mathrm{VI})$ only (Group 4) showed a significant $(\mathrm{p}<0.05)$ increase as compared with control which matches the observations in a study by Suljević et al., 2020 [27]. However, in this study, the white blood cell count was normalized in the groups treated with the leaf pulp of the plant treated group when compared with the control; this could be as a result of the antiproliferative property of $C$. edulis extract, thereby reducing the rate of production of immature white blood cells [28].

Exposure to $\mathrm{Cr}$ (VI) has been discovered to activate the oxidation of free radicals and cause lipid peroxidation, which is closely related to cellular or organ toxicity. The products of lipid peroxidation and free radicals cause changes in the function and structure of the cellular membrane that may lead to cell injury. Toxic metals have been discovered to produce oxidative stress in cell lines and organs $[29,30]$. In this study, the scavenging enzymes (SOD \& CAT) activity was reduced in both the liver and kidney; also, the level of malondialdehyde (MDA) in the liver and kidney was significantly reduced increased, thereby confirming the induction of oxidative stress in the organs. This is in consonance with studies by Karaulov et al., 2019 and Zhao et al., 2019; Zheng et al., 2020 where induction of rats with chromium VI led to increased MDA level and reduction in SOD and CAT levels. Administration with C. edulis extract caused a significant increase in the levels of SOD and CAT in the liver and kidney and a significant decrease in MDA level in the kidney and liver [31, 32]. This confirms the antioxidative property of $C$. edulis extract. The plant extract can chelate copper and iron ions because the elevation in these ions could greatly increase oxidative stress [6]. There was a decrease in the level of Glutathione-s-transferase (GST) in the kidney and liver of the group 
treated with only $\mathrm{Cr}$ (VI), and this was also observed in the livers of common goby (Pomatoschistus microps) [33] and freshwater fish such as Japanese medaka [34]; however, the decrease in GST contradicts the study carried out on the liver of marine medaka (Oryzias melastigma) by Ni et al., 2020 where an increase in the GST level was reported in the liver of the marine medaka (Oryzias melastigma) [35]. In the groups treated with $C$. edulis extract, Glutathione Transferase (GST) level was significantly increased in the liver and kidney, thereby signifying a level of injury recovery in both organs.

$\mathrm{Cr}$ (VI) has been discovered to cause damage to proximal tubular epithelial cells [32, 36], degeneration of the renal tubular epithelial, and the basement membrane of the Bowman's capsule [37]. Elevation in plasma urea in chromium-treated animals is one of the important biomarkers of kidney damage indicating a systemic toxic effect of $\mathrm{Cr}$ (VI) in the rats, and this elevated level was observed in the group treated with $\mathrm{Cr}$ (VI), indicating renal dysfunction. In the groups treated with $C$. edulis extract, a significant decrease in the urea level was observed, which means that the extract ameliorated the kidney. The creatinine levels showed no significant change, which is following research by Alijagic et al., 2017 where the administration of $\mathrm{Cr}$ (VI) had no significant effect on the creatinine level of the quails [38]. In this study, liver damage was indicated by the significantly decreased AST, ALT, and ALP plasma levels in the chromium-treated rat. This was observed in a study where various chromium compounds were administered to Wistar rats [26]. However, a contrary result was observed in the study by Saha et al., 2017 where AST, ALT, and ALP levels were elevated [22]. However, an increase in the levels of AST, ALP and ALT were observed in the groups treated with $C$. edulis extract compared with the group treated with only $\mathrm{Cr}$ (VI).

The decrease in the protein levels observed in the group treated with $\mathrm{Cr}$ (VI) compared with another group could result from impaired protein production [39]. A decrease in protein level in groups exposed to Cr (VI) was also observed in studies by Saha et al., 2017; Ko et al., 2019; Suljević et al.,2020 [22, 27, 40]. The decrease in protein levels could also result from a reduction in the levels of albumins and, to a lesser extent, globulins. The protein levels were increased in the groups administered with $C$. edulis extract, which shows that the extract played a role in reversing the impaired protein production. $\mathrm{Cr}$ (VI) has been reported to have significant effects on lipid metabolism, and in this study, an increase in the LDL level and a decrease in HDL level were observed, which is in consonance with the study by Shil \& Pal, 2019 which could be a result of impaired reverse transport of cholesterol from the blood to the liver [41]. However, there was a decrease in the triglyceride level, which was also observed in Japanese quails, which could be of the toxic effect of $\mathrm{Cr}$ (VI) on the hepatic tissue, which could inhibit the production of triglycerides [39]. An imbalance in the level of electrolytes could influence the functioning of the kidneys and acid-base balance, which could be an indicator of toxicity in the body. In this study, the levels of sodium, potassium, and chloride were elevated, resulting from the toxic impact of $\mathrm{Cr}$ (VI) on the rats. On the contrary, a decrease in the level of these electrolytes was observed in the study by Suljević et al., 2020 [27].

\section{Conclusions}

A result from the research shows that the leaf pulp of $C$. edulis reduced the toxicity caused by chromium VI, and it was observed that the reduction was greater in the therapeutic than in the pre-treatment groups. Further research should be carried out to determine the longterm effect of the plant on the toxicity of chromium VI. Furthermore, a dose-dependent study 
could be carried out to determine the best dose that could be used to reduce the toxicity caused by this heavy metal.

\section{Funding}

This research received no external funding.

\section{Acknowledgments}

This research has no acknowledgment.

\section{Conflicts of Interest}

The authors declare no conflict of interest.

\section{References}

1. Akinyede, K.A.; Ekpo, O.E.; Oguntibeju, O.O. Ethnopharmacology, Therapeutic Properties and Nutritional Potentials of Carpobrotus edulis: A Comprehensive Review. Scientia Pharmaceutica 2020, 88, https://doi.org/10.3390/scipharm88030039.

2. Cock, I.E.; van Vuuren, S.F. South African food and medicinal plant extracts as potential antimicrobial food agents. Journal of Food Science and Technology 2015, 52, 6879-6899, https://doi.org/10.1007/s13197-0151806-3.

3. Hafsa, J.; Hammi, K.M.; Khedher, M.R.B.; Smach, M.A.; Charfeddine, B.; Limem, K.; Majdoub, H. Inhibition of protein glycation, antioxidant and antiproliferative activities of Carpobrotus edulis extracts. Biomed. Pharmacother. 2016, 84, 1496-1503, https://doi.org/10.1016/j.biopha.2016.11.046.

4. Akhalwaya, S.; van Vuuren, S.; Patel, M. An in vitro investigation of indigenous South African medicinal plants used to treat oral infections. J. Ethnopharmacol. 2018, 210, 359-371, https://doi.org/10.1016/j.jep.2017.09.002.

5. Castañeda-Loaiza, V.; Placines, C.; Rodrigues, M.J.; Pereira, C.; Zengin, G.; Uysal, A.; Jeko, J.; Cziáky, Z.; Reis, C.P.; Gaspar, M.M. If you cannot beat them, join them: Exploring the fruits of the invasive species Carpobrotus edulis (L.) N.E. $\mathrm{Br}$ as a source of bioactive products. Ind. Crop. Prod. 2020, 144, https://doi.org/10.1016/j.indcrop.2019.112005.

6. Rocha, M.I.; Rodrigues, M.J.; Pereira, C.; Pereira, H.; da Silva, M.M.; da Rosa Neng, N.; Nogueira, J.M.F.; Varela, J.; Barreira, L.; Custódio, L. Biochemical profile and in vitro neuroprotective properties of Carpobrotus edulis L., A medicinal and edible halophyte native to the coast of South Africa, South African Journal of Botany 2017; 111, 222-231, https://doi.org/10.1016/j.sajb.2017.03.036.

7. DesMarias, T.L.; Costa, M. Mechanisms of chromium-induced toxicity. Current Opinion in Toxicology 2019, 14, 1-7, https://doi.org/10.1016/j.cotox.2019.05.003.

8. Karaulov, A.V.; Renieri, E.A.; Smolyagin, A.I.; Mikhaylova, I.V.; Stadnikov, A.A.; Begun, D.N.; Tsarouhas, K.; Buha Djordjevic, A.; Hartung, T.; Tsatsakis, A. Long-term effects of chromium on morphological and immunological parameters of Wistar rats. Food and Chemical Toxicology 2019, 133, https://doi.org/10.1016/j.fct.2019.110748.

9. Sun, H.; Brocato, J.; Costa, M. Oral Chromium Exposure and Toxicity. Current Environmental Health Reports 2015, 2, 295-303, https://doi.org/10.1007/s40572-015-0054-z.

10. Reitman, S.; Frankel, S. A colorimetric method for the determination of serum glutamic oxaloacetic and glutamic pyruvic transaminases. Am. J. Clin. Pathol. 1957, 28, 56-63, https://doi.org/10.1093/ajcp/28.1.56.

11. Trinder, P. Oxidase determination of plasma cholesterol as cholest-4-en-3-one using iso-octane extraction. Ann CIin Biochem 1981, 18, 64-70, https://doi.org/10.1177/000456328101800202.

12. Trinder, P.; Webster, D. Determination of HDL-Cholesterol Using 2,4,6-Tribromo-3-Hydroxybenzoic Acid with a Commercial CHOD_PAP Reagent. Annals of Clinical Biochemistry 1984, 21, 430-433, https://doi.org/10.1177/000456328402100516.

13. Veniamin, M.P.; Vakirtzi-Lemonias, C. Chemical basis of the carbamidodiacetyl micromethod for estimation of urea, citrulline, and carbamyl derivatives. Clin Chem 1970, 16, 3-6.

14. Varshney, R.; Kale, R.K. Effects of Calmodulin Antagonists on Radiation-induced Lipid Peroxidation in Microsomes. International Journal of Radiation Biology 1990, 58, 733-743, http://dx.doi.org/10.1080/09553009014552121.

15. Pabst, M.J.; Habig, W.H.; Jakoby, W.B. Glutathione S-Transferase A: A Novel Kinetic Mechanism In Which The Major Reaction Pathway Depends On Substrate Concentration. Journal of Biological Chemistry 1974, 249, 7140-7148, https://doi.org/10.1016/S0021-9258(19)42084-X. 
16. Misra, H.P.; Fridovich, I. The Role of Superoxide Anion in the Autooxidation of Epinephrine and a Simple Assay of SOD. Journal of Biological Chemistry 1972. 247, 3170-3175, https://doi.org/10.1016/S00219258(19)45228-9.

17. Sinha, A.K. Colorimetric assay of catalase. Analytical Biochemistry 1972, 47, 389-394, https://doi.org/10.1016/0003-2697(72)90132-7.

18. Taghizadeh, S.F.; Davarynejad, G.; Asili, J.; Nemati, S.H.; Rezaee, R.; Goumenou, M.; Tsatsakis, A.M.; Karimi, G. Health risk assessment of heavy metals via dietary intake of five pistachio (Pistacia vera L.) cultivars collected from different geographical sites of Iran. Food and Chemical Toxicology 2017, 107, 99107, https://doi.org/10.1016/j.fct.2017.06.035.

19. Renieri, E.A.; Safenkova, I.V.; Alegakis, A.K.; Slutskaya, E.S.; Kokaraki, V.; Kentouri, M.; Dzantiev, B.B.; Tsatsakis, A.M. Cadmium, lead and mercury in muscle tissue of gilthead seabream and seabass: Risk evaluation for consumers. Food and Chemical Toxicology 2019, 124, 439-449, https://doi.org/10.1016/j.fct.2018.12.020.

20. Abedi, Z.; Khalesi, M.K.; Eskandari, S.K. Biochemical and Hematological Profiles of Common Carp (Cyprinus Carpio) under Sublethal Effects of Trivalent Chromium. Iranian Journal of Toxicology 2013, 7, 782-792.

21. Kim, J.-H.; Kang, J.-C. The chromium accumulation and its physiological effects in juvenile rockfish, Sebastes schlegelii, exposed to different levels of dietary chromium $(\mathrm{Cr} 6+)$ concentrations. Environmental Toxicology and Pharmacology 2016, 41, 152-158, https://doi.org/10.1016/j.etap.2015.12.001.

22. Saha, J.; Choudhuri, S.; Choudhuri, D. Effect of subchronic exposure to chromium on hematological and biochemical parameters of male albino rat. Asian Journal of Pharmaceutical and Clinical Research 2017, 10 .

23. Kandpal, V.; Kumar, D.; Bisht, R. Protective Effect of Vitamin E on Haematological Parameters in Chronic Toxicity of Hexavalent Chromium in Laboratory Chicks. JDDT [Internet] 2019, 9, 388-92.

24. Kumar, R.; Banerjee, T.K. Arsenic induced hematological and biochemical responses in nutritionally important catfish Clarias batrachus (L.). Toxicology Reports 2016, 3, 148-152, https://doi.org/10.1016/j.toxrep.2016.01.001.

25. Zhumabaeva, A.N.; Zarishnyak, N.V.; Bekmukhambetov, E.Z. Immunotropic Effects of Hexavalent Chromium Soluble Compounds on the Thymus and Peripheral Blood Values in a Subacute Experiment. Bulletin of Experimental Biology and Medicine 2014, 156, 512-517, https://doi.org/10.1007/s10517-0142387-2.

26. Lebedev, S.; Gavrish, I.; Rusakova, E.; Kvan, O.; Gubaidullina, I. Influence of various chromium compounds on physiological, morpho-biochemical parameters, and digestive enzymes activity in Wistar rats. Trace Elements and Electrolytes Munich 2018, 35, 242, https://doi.org/10.5414/TEX0155419.

27. Suljević, D.; Sulejmanović, J.; Fočak, M.; Halilović, E.; Pupalović, D.; Hasić, A.; Alijagic, A. Assessing hexavalent chromium tissue-specific accumulation patterns and induced physiological responses to probe chromium toxicity in Coturnix japonica quail. Chemosphere 2021, 266, https://doi.org/10.1016/j.chemosphere.2020.129005.

28. Omoruyi, S.I.; Enogieru, A.B.; Ekpo, O.E. Preliminary cytotoxic activity of sutherladia frutescens and Carpobrotus edulis on malignant glioblastoma cells. Trop. J. Nat. Prod. Res. 2019, 3, 175-179, https://doi.org/10.26538/tjnpr/v3i5.5.

29. Engin, A.B.; Engin, E.D.; Golokhvast, K.; Spandidos, D.A.; Tsatsakis, A.M. Glutamate-mediated effects of caffeine and interferon- $\gamma$ on mercury-induced toxicity. Int. J. Mol. Med. 2017, https://doi.org/10.3892/ijmm.2017.2937.

30. Wallace, D.; Spandidos, D.; Tsatsakis, A.; Schweitzer, A.; Djordjevic, V.; Djordjevic, A. Potential interaction of cadmium chloride with pancreatic mitochondria: implications for pancreatic cancer. Int. J. Mol. Med. 2019, 44, 1-12, https://doi.org/10.3892/ijmm.2019.4204.

31. Zhao, Y.; Yan, J.; Li, A.-P.; Zhang, Z.-L.; Li, Z.-R.; Guo, K.-J.; Zhao, K.-C.; Ruan, Q.; Guo, L. Bone marrow mesenchymal stem cells could reduce the toxic effects of hexavalent chromium on the liver by decreasing endoplasmic reticulum stress-mediated apoptosis via SIRT1/HIF-1 $\alpha$ signaling pathway in rats. Toxicology Letters 2019, 310, 31-38, https://doi.org/10.1016/j.toxlet.2019.04.007.

32. Zheng, X.; Li, S.; Li, J.; Lv, Y.; Wang, X.; Wu, P.; Yang, Q.; Tang, Y.; Liu, Y.; Zhang, Z. Hexavalent chromium induces renal apoptosis and autophagy via disordering the balance of mitochondrial dynamics in rats. Ecotoxicology and Environmental Safety 2020, 204, https://doi.org/10.1016/j.ecoenv.2020.111061.

33. Luís, L.G.; Ferreira, P.; Fonte, E.; Oliveira, M.; Guilhermino, L. Does the presence of microplastics influence the acute toxicity of chromium(VI) to early juveniles of the common goby (Pomatoschistus microps)? A study with juveniles from two wild estuarine populations. Aquatic Toxicology 2015, 164, 163174, https://doi.org/10.1016/j.aquatox.2015.04.018.

34. Chen, H.; Mu, L.; Cao, J.; Mu, J.; Klerks, P.L.; Luo, Y.; Guo, Z.; Xie, L. Accumulation and effects of Cr(VI) in Japanese medaka (Oryzias latipes) during chronic dissolved and dietary exposures. Aquatic Toxicology 2016, 176, 208-216, https://doi.org/10.1016/j.aquatox.2016.05.002. 
35. Ni, X.; Wan, L.; Liang, P.; Zheng, R.; Lin, Z.; Chen, R.; Pei, M.; Shen, Y. The acute toxic effects of hexavalent chromium on the liver of marine medaka (Oryzias melastigma). Comparative Biochemistry and Physiology Part C: Toxicology \& Pharmacology 2020, 231, https://doi.org/10.1016/j.cbpc.2020.108734.

36. Lin, T.-J.; Huang, Y.-L.; Chang, J.-S.; Liu, K.-T.; Yen, M.-C.; Chen, F.-W.; Shih, Y.-L.; Jao, J.-C.; Huang, P.-C.; Yeh, I.J. Optimal dosage and early intervention of L-ascorbic acid inhibiting K2Cr2O7-induced renal tubular cell damage. Journal of Trace Elements in Medicine and Biology 2018, 48, 1-7, https://doi.org/10.1016/j.jtemb.2018.02.022.

37. Soudani, N.; Sefi, M.; Bouaziz, H.; Chtourou, Y.; Boudawara, T.; Zeghal, N. Nephrotoxicity induced by chromium (VI) in adult rats and their progeny. Human \& experimental toxicology 2011, 30, 1233-1245, https://doi.org/10.1177/0960327110387454.

38. Alijagic, A.; Islamagić, E.; Focak, M. Suljević, D. Effects of trivalent and hexavalent dietary chromium on blood biochemical profile in Japanese quails. Bulgarian Journal of Veterinary Medicine 2017, 21, 470-477, https://doi.org/10.15547/bjvm.1095.

39. Ramesh, M.; Sankaran, M.; Veera-Gowtham, V.; Poopal, R.K. Hematological, biochemical and enzymological responses in an Indian major carp Labeo rohita induced by sublethal concentration of waterborne selenite exposure. Chemico-biological interactions 2014, 207, 67-73, https://doi.org/10.1016/j.cbi.2013.10.018.

40. Ko, H.-D.; Park, H.-J.; Kang, J.-C. Change of growth performance, hematological parameters, and plasma component by hexavalent chromium exposure in starry flounder, Platichthys stellatus. Fisheries and Aquatic Sciences 2019, 22, https://doi.org/10.1186/s41240-019-0124-5.

41. Shil, K.; Pal, S. Metabolic and morphological disorientations in the liver and skeletal muscle of mice exposed to hexavalent chromium. Comparative Clinical Pathology 2019, 28, 1729-1741, https://doi.org/10.1007/s00580-019-03014-w. 